\title{
Espectromorfologia e Processos de Estruturação
}

\author{
Denis Smalley | City, University of London | Inglaterra \\ Germán E. Gras | Universidade Estadual do Ceará | Brasil \\ Thaís A. Aragão | Universidade Federal do Ceará | Brasil
}

\begin{abstract}
Resumo: Espectromorfologia refere-se às maneiras pelas quais espectros de frequência são moldados ao longo do tempo. As respostas dos ouvintes a sons e música derivam de respostas psicológicas à identidade energética, ao comportamento e à organização dos tipos de som nos contextos das estruturas sonoras. Arquétipos instrumentais são uma útil base de referência inicial, a partir da qual uma variedade mais ampla de modelos morfológicos e combinações pode ser elaborada. Isso leva a uma discussão sobre tipos de movimento, que, na mente ouvinte, podem estar ligados à experiência real ou imaginária. $\mathrm{O}$ movimento é expresso através de tendências orientadas a metas, de contornos externos (evocando, a noção de gesto), ou através de comportamentos texturais internos. A formação e o movimento dos arquétipos espectromorfológicos fornecem modelos para a definição de funçôes estruturais e processos de estruturação: interpretamos a importância das ações combinadas dos participantes estruturais à medida que ouvimos por períodos mais ou menos prolongados. Finalmente, são discutidos os aspectos espaciais da espectromorfologia e a influência do ambiente de escuta.
\end{abstract}

Palavras-chave: Espectromorfologia, Tipos de movimento, Processos de estruturação, Espaço.

\begin{abstract}
Spectromorphology refers to the ways in which frequency spectra are shaped over time. Listeners' responses to sounds and music derive from psychological responses to the energetic identity, behaviour and organisation of sound-types in the contexts of sounding structures. Instrumental archetypes are a useful initial reference base, from which a broader range of morphological models and combinations can be elaborated. This leads to a discussion of types of motion, which in the listening mind may be linked to real or imagined experience. Motion is expressed both through the goal-directed tendencies of external contours (evoking the notion of gesture) and through internal textural behaviours. The shaping and motion of spectromorphological archetypes provide models for defining structural functions and structuring processes: we interpret the significance of the combined actions of structural participants as we listen over shorter and longer stretches of time. Finally, the spatial aspects of spectromorphology and the influence of the listening environment are discussed.
\end{abstract}

Keywords: Spectromorphology, Types of motion, Structuring processes, Space. 


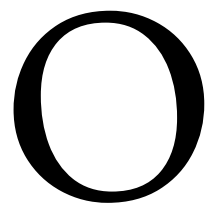
desenvolvimento da música ocidental no século XX é dominado por uma bifurcação histórica na linguagem musical. A tonalidade, com suas relaçóes harmônicas e melódicas organizadas de maneira metricamente contínua, permaneceu sendo a linguagem vernacular, aquela absorvida inconscientemente desde o nascimento. Enquanto isso, a outra via dessa forquilha, na sua forma mais recente, é representada pela espectromorfologia ${ }^{1}$. A espectromorfologia é uma abordagem dos materiais sonoros e estruturas musicais que se concentra no espectro das alturas disponíveis e na sua formação ao longo do tempo. Ao abraçar o quadro total de altura e de tempo, está implicado que a linguagem vernacular se limita a uma pequena área do universo musical. Desenvolvimentos tais como a atonalidade, o serialismo integral, a expansão de instrumentos de percussão e o advento da mídia eletroacústica, tudo isso contribui para o reconhecimento da musicalidade que é inerente a todos os sons. Mas foram a gravação do som, a tecnologia eletrônica e, mais recentemente, o computador que permitiram uma exploração musical que antes não era possível. A espectromorfologia é uma maneira de perceber e conceber esses novos valores resultantes de uma cadeia de influências que se acelerou desde a virada do século XIX para o século XX. Como tal, ela é uma herdeira da tradição musical ocidental que, ao mesmo tempo, altera os critérios musicais e exige novas percepções.

A espectromorfologia encontra seu verdadeiro lar na música eletroacústica, mas não está presa a ela. Embora os instrumentos também possam ser moldados de maneira espectromorfológica, instrumentos de sopro e de cordas tradicionais, harmônicos em sua constituição espectral, foram concebidos e desenvolvidos para uma música harmônica. Mesmo que as técnicas modernas de execução ${ }^{2}$ pareçam nos permitir escapar dos limites harmônicos, essa é uma liberdade temporária e ilusória, subvertida pela natureza tradicional dos instrumentos. O futuro da performance ao vivo deve se dar com novos instrumentos.

A voz, por causa de seus íntimos vínculos humanos, nunca pode desaparecer do uso musical. Por meio da linguagem, ela tem sido infundida em mais de mil anos de música ocidental, incluindo a música puramente instrumental (GEORGIADES, 1982). É, portanto, inevitável que a voz e a

\footnotetext{
${ }^{1}$ A expressão 'spectromorphology' é preferível ao termo schaefferiano "tipo-morfologia" pelos motivos dados neste texto. "O tratado dos objetos musicais" de Pierre Schaeffer (1966) é a primeira obra significativa a elaborar critérios espectromorfológicos, e fornece os fundamentos para este capítulo.

${ }^{2}$ Atualmente conhecidas como técnicas estendidas (N. de T.).
} 
linguagem continuem a residir no coração da música vernacular, enquanto na outra via da bifurcação sua influência foi se enfraquecendo à medida que a espectromorfologia se infiltrava no pensamento musical moderno. Como fontes sonoras, no entanto, a linguagem e os sons vocais encontram um novo valor, resultante do contato com a mídia eletroacústica.

Mesmo que o som real de estruturas baseadas em uma abordagem espectromorfológica frequentemente pareça deixar vozes e instrumentos para trás, sua influência formativa ainda persiste por meio do gesto: as formas espectrais e as sequências de formas, criadas pela energia da articulação física e vocal. Ainda que o comportamento espectral interno dos sons possa não mais refletir abertamente a inspiração que tira de instrumentos e vozes, os vínculos tangíveis com a humanidade exigem ser preservados por meio do gesto.

Recentemente, foi concedido aos sons dos fenômenos ambientais status igual ao da voz e do instrumento. A aceitação de sons ambientais completa os modelos sonoros para a composição musical: os sons da linguagem e da expressão humana em geral, fenômenos naturais, sons criados intencionalmente pela agência humana (não apenas aqueles de instrumentos musicais), e sons não intencionais de origem humana. A exploração musical dessas fontes e suas extensões imaginativas através do processamento e síntese de sinais de áudio são tarefa das artes eletroacústicas.

Os ouvintes só podem apreender a música se descobrirem uma afinidade perceptiva com seus materiais e sua estrutura. Tal afinidade depende da parceria entre compositor e ouvinte, mediada pela percepção auditiva. Hoje, precisamos reafirmar continuamente a primazia da experiência aural na música. A herança do formalismo do século XX e a propensão contínua dos compositores na busca por apoio em modelos não musicais produziram o indesejável efeito colateral de enfatizar conceito em detrimento de percepção. Tomar de empréstimo conceitos de disciplinas não musicais é comum e pode ser útil. Porém, a menos que o conceito seja verificado ou mitigado pelo ouvido, é sempre possível que o ouvinte seja levado ao ostracismo. A percepção auditiva é frágil, volúvel, empírica e, portanto, representa uma ameaça àqueles músicos e pesquisadores que tenham dificuldade em aceitar a insegurança de sua subjetividade. A primazia da percepção é 
inquestionável, pois sem ela a experiência musical não existe.

Precisamos concentrar nossa atenção na percepção musical e, em particular, no agora extenso repositório de música eletroacústica à nossa disposição. É de minha experiência - por ensinar, participar de concertos e programá-los, e conversar com intérpretes e compositores de música eletroacústica - que há um notável consenso sobre a eficácia ou fracasso de determinadas obras musicais, indicando assim uma avaliação instintiva dos novos valores espectromorfológicos. A prática da escuta e a observação perceptiva do processo de escuta devem, portanto, constituir a base de qualquer investigação musical que procure explicar o funcionamento da espectromorfologia.

A falta de uma terminologia compartilhada é um sério problema para a música eletroacústica, porque uma descrição dos materiais sonoros e de seus relacionamentos é um pré-requisito para a discussão avaliativa. Ao procurar palavras apropriadas, somos obrigados a utilizar termos não musicais porque o circunscrito vocabulário inventado para uma explicação puramente musical é muito limitado para fins espectromorfológicos. Tais empréstimos semânticos imediatamente indicam que a música envolve mimese: materiais e estruturas musicais encontram semelhanças e ecos no mundo não musical. Essas relações com a experiência humana podem ser óbvias, tangíveis e conscientes, ou disfarçadas, enganosas e inconscientes. No entanto, para descobrir o que acontece na vida de um som ou estrutura sonora, ou o que nos atrai sobre a qualidade ou a forma do som, devemos ignorar temporariamente como o som foi feito ou aquilo que o causou, concentrando-nos em mapear seu processo espectromorfológico. Por exemplo, ao tentar descrever o som de um carro que se aproxima, devemos esquecer que ele é um carro e ignorar tudo o que está associado à 'condição-de-carro', limitando nossas observações auditivas a descobrir como o espectro do som muda com o tempo. Esse processo investigativo é conhecido como escuta reduzida ${ }^{3}$ - "reduzida" porque rejeitar deliberadamente a fonte do som reduz o escopo da experiência musical normal. Tal atitude de escuta abstrata não deve ser considerada como um instrumento puramente investigativo,

\footnotetext{
3“Escuta reduzida” (écoute réduite) é um conceito de Pierre Schaeffer. Ver Schaeffer (op. cit.) e M. Chion (1983), para uma discussão mais aprofundada.
} 
separado da experiência musical real. Pode-se imaginar um contexto em que o design espectral do som do carro possa estar associado a outros sons de design similar ou relacionado. Dessa maneira, o compositor pode manipular o contexto para que o ouvinte seja levado a seguir os aspectos abstratos do design do som, ao invés de pensar no significado dos carros como objetos. Por outro lado, pode ser criado um contexto musical onde o som do carro é usado para fazer uma declaração sobre carros como símbolos culturais. Em última análise, ao explicar o papel do som do carro em seu contexto musical, devemos explorar os dois aspectos de seu significado.

Todos os sons possuem esse potencial duplo - os aspectos abstratos e concretos do som ${ }^{4}-\mathrm{e}$ todas as estruturas musicais encontram equilíbrio em algum lugar entre os dois, embora possa variar muito, entre os ouvintes, a maneira como exatamente eles são balanceados. Isso ocorre porque todos os ouvintes têm uma prática considerável no aspecto concreto da vida cotidiana, enquanto uma abordagem abstrata precisa ser adquirida. No entanto, o ouvinte acostumado com uma atitude perceptiva mais abstrata pode facilmente desconsiderar a dimensão mimética da interpretação de sons. Equilibrar atitudes abstratas e concretas é, portanto, uma questão de competência e intenção.

Esse equilíbrio é ainda mais complicado porque os aspectos abstratos e concretos nem sempre são o que parecem. A música está sempre relacionada de alguma maneira à experiência humana, o que significa que a mimese está sempre em ação, mesmo na música considerada abstrata - ainda que essa mimese seja notadamente difícil de explicar, principalmente porque a linguagem muitas vezes representa um filtro inadequado para interpretar a experiência musical. Em contrapartida, um contexto musical que parece depender inteiramente do impacto mimético é igualmente ilusório. $\mathrm{O}$ poder que uma imagem-som concreta possui para retratar coisas, eventos ou circunstâncias psicológicas repousa não apenas no imediatismo das próprias imagens, mas na maneira como os sons são construídos e combinados - sua espectromorfologia -, e isto envolve o uso da escuta reduzida para investigar a dimensão mais abstrata.

Neste trabalho, a terminologia frequentemente evoca analogias extramusicais e muitas palavras foram selecionadas por causa de suas associações. Ao adotar uma abordagem espectromorfológica, devemos usar a escuta reduzida como a principal estratégia investigativa,

\footnotetext{
${ }^{4}$ A relação entre "abstrato" e "concreto" é mais complexa do que esta discussão sugere. Ver Schaeffer (op. cit.) e Chion (op. cit.).
} 
lembrando que uma terminologia baseada em analogias logo convida necessárias interpretações miméticas. Primeiro examinaremos como as alturas são combinadas para formar diferentes tipos sonoros: a tipologia espectral. Poderemos, então, acompanhar as maneiras pelas quais os tipos espectrais são organizados em formas temporais ou morfologias básicas. Isso nos levará a uma discussão mais ampla, baseada na ideia de movimento: as tendências direcionais de formas sonoras e combinações de formas. Poderemos, então, considerar os princípios de estruturação com base no modo como o ouvinte experimenta o tempo e o movimento musical.

\section{Tipologia espectral}

O termo 'espectro' abrange a totalidade das frequências perceptíveis. Ele substitui a antiga divisão do domínio das frequências em 'altura' e 'timbre' - termos muito intimamente associados às noções tradicionais de suas funçôes no contexto da música harmônica. A ideia de que as 'notas', as portadoras da informação sobre altura, estão vestidas com matizes de timbres não é eliminada; está apenas alocada na perspectiva mais ampla dos tipos espectrais.

A tipologia espectral não pode ser separada do tempo de modo realista: os espectros são percebidos no curso do tempo, e o tempo é percebido como movimento espectral. Portanto, até que a morfologia e o movimento sejam abordados, apenas é possível uma discussão preliminar e limitada.

Três tipos espectrais fornecem pontos de referência basilares para a identificação espectral: nota, nódulo e ruido (ver Figura 1). O tipo nota, cujo interesse é a percepção de uma altura discreta ou alturas, pode ser subdividido em três categorias: nota propriamente dita, espectros harmônicos e espectros inarmônicos.

A nota propriamente dita abarca a percepção tradicional de altura: alturas absolutas, combinaçôes intervalares e de acordes. Isso significa que, embora a nota possa ser espectralmente 
colorida, estamos mais interessados na sua fundamental do que em seus sobretons 5 . No sistema tonal, as notas são as portadoras primordiais de informaçóes. Se elas forem usadas em qualquer medida, particularmente em contextos intervalares ou harmônicos, o sistema tonal pode ser evocado e torna-se mais difícil persuadir o ouvido a observar qualidades espectrais, tal é a primazia da percepção da nota tanto como um fenômeno natural quanto cultural. No entanto, agora entendemos que as fronteiras entre altura e 'timbre' são muito imprecisas, e estão sujeitas a demarcações perceptivas deslizantes, entre as quais podemos transitar com fluência se o contexto musical o permitir, e se tivermos adquirido habilidades apropriadas de discernimento. Atitudes tonais, portanto, não são abandonadas ou segregadas, mas subsumidas, e podemos encontrar um lugar para a nota propriamente dita no território, em um dos extremos do continuun tipológico.

FIGURA 1 - Tipologia espectral

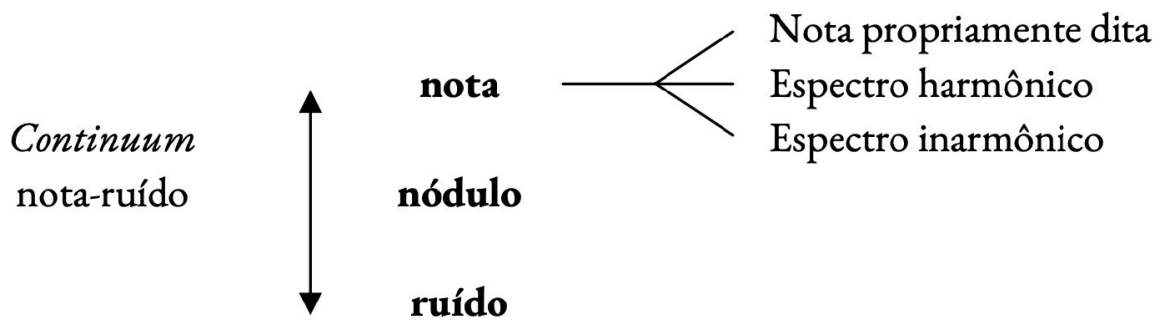

O passo desde a nota até o espectro harmônico não é decisivo. Em um espectro harmônico, os intervalos da série harmônica governam. Dependerá de hábitos de discernimento e do contexto musical que a atenção perceptiva seja atraída para a fundamental ou para as relações harmônicas do espectro. $\mathrm{O}$ contexto é crucial para a interpretação espectral. Em uma tradicional nota instrumental ou vocal, o espectro harmônico é equilibrado e fundido a tal ponto que os componentes espectrais são em grande parte indiscerníveis - ou pelo menos ignorados - pelo ouvido. Se essa fusão se afrouxa, o foco harmônico se torna possível. Quando um espectro harmônico é mais perceptível do que a fundamental, seus componentes espectrais podem ser entendidos como valores composicionais. Essa mudança de foco pode ser demonstrada ouvindo uma nota grave do piano. Ouvida a uma distância habitual de escuta, a nota propriamente dita predomina. Se amplificada ou

\footnotetext{
${ }^{5}$ Sobretons são as parciais acima da fundamental, sejam estas harmônicas ou inarmônicas (N. de T.).
} 
ouvida mais intimamente, os componentes espectrais da nota e a fisionomia temporal deles tornamse aparentes. A mudança de foco da nota propriamente dita ao comportamento interno dos componentes preparou a casa para um novo potencial musical, uma vez que o meio eletroacústico viabiliza a composição, decomposição e o desenvolvimento dos interiores espectrais.

Tal afirmação é ainda mais significativa para os espectros inarmônicos, pois, sem a assistência da tecnologia, os espectros inarmônicos nunca poderiam se tornar materiais musicais verdadeiramente viáveis. Espectros inarmônicos são modelados no comportamento de, por exemplo, muitos sons metálicos cujos componentes espectrais geralmente não têm relação com a série harmônica. Espectros inarmônicos não estão distribuídos na ordem sistemática previsível apresentada pelos espectros harmônicos. Seus componentes dispersos geralmente resistem à fusão e podem, portanto, ser percebidos a partir de uma variedade de ângulos, provocando uma frutífera ambiguidade de foco. Um espectro inarmônico pode conter intervalos que evocam referências tonais; espectros inarmônicos simples podem ser interpretados como relaçóes próximas a espectros harmônicos; exemplos mais complexos podem incluir intervalos harmônicos e inarmônicos, ao lado de densidades nodais que desafiam a definição. Quem compõe pode dar ênfase a um ângulo focal particular, manipulando o comportamento do componente em direção a um dos vários resultados espectrais: inarmonicidades, harmonicidades, intervalos tonais, ou as mais compactas densidades de tipologias nodais e de ruído. Espectros inarmônicos são ambiguamente multidimensionais.

Um espectro nodal é uma faixa ou nódulo de sons que resiste à identificação de altura. Certos instrumentos de percussão fornecem modelos familiares. Um prato ouvido à distância é percebido de maneira nodal, no sentido de que tendemos a não identificar uma altura definida, e sim perceber suas qualidades como uma ressonância rica, metálica e unificada. Porém, se escutarmos mais de perto ou amplificarmos o prato, podemos descobrir uma combinação espectral interna de notas, harmônicos, inarmônicos ou componentes nodais. Um espectro nodal também pode ser considerado como uma densidade sonora cuja qualidade compacta unificada torna difícil ouvir sua estrutura interna de alturas. Um cluster de notas fornece um exemplo simples.

No continuum nota-ruido, o espectro nodal encontra-se em direção ao limite do ruído. A densidade de um espectro de ruido é tão comprimida que é impossível ouvir qualquer estrutura interna de alturas. Se percebermos qualidades internas, é provável que elas se apresentem como 
movimentos granulares ou de partículas, e não como fenômeno de altura. O ruído não é monocromático, mas um fenômeno variado, não menos diverso que os outros tipos espectrais. Modelos naturais são fornecidos pelo vento e pelo mar.

Acabamos de passar pela difusa zona de amortecimento $^{6}$ entre a nota e o ruído como resultado do aumento da densidade e compressão espectral. Isto pode ser uma propriedade inerente aos materiais sonoros escolhidos ou pode ser o resultado de sobreposições espectrais compostas. Destacaremos essa zona de amortecimento chamando-a de continuum de eflúvio de alturas. Eflúvio refere-se ao estado em que o ouvido não consegue mais separar os espectros em suas alturas componentes. Confrontado com um estado de eflúvio, o ouvinte precisa mudar a estratégia focal, uma vez que o interesse auditivo é forçado a deixar de traçar o comportamento dos componentes internos e acompanhar mais a dinâmica de modelagem externa. Assim, o contexto altera o nível em que o ouvido pode responder à estrutura musical. Voltaremos a esse tema quando discutirmos sobre estruturas.

O potencial estrutural dos atributos espectrais além da nota propriamente dita é aproveitado comparando, relacionando e transformando tipos espectrais e suas combinações. A nota propriamente dita pertence a um sistema cardinal único, baseado na capacidade do ouvido de perceber valores de altura absolutos. Se existe algum sistema espectral a ser descoberto ou criado além da nota propriamente dita, este é um sistema ordinal, baseado apenas em graus relacionais, e não em graus absolutos. ${ }^{7}$

Para concretizar todo o potencial musical de atitudes espectrais mais recentes, devemos agora considerar sua forma temporal, conhecida como morfologia.

\footnotetext{
${ }^{6}$ Algumas analogias extramusicais evocadas por Smalley relacionam-se com o espaço. Zona de amortecimento, ou zona tampão, é o entorno de uma unidade de conservação ambiental, uma faixa que visa proteger o interior dos impactos de atividades externas. Na geopolítica, refere-se a uma zona neutra de segurança, desmilitarizada, protegida ( $N$. de $T$.).

${ }^{7}$ Os conceitos de "cardinal" e "ordinal" são de Schaeffer. Mais informações podem ser encontradas em Chion (1983, p. 43-48).
} 


\section{Morfologia}

As morfologias da nota instrumental são uma conveniente introdução aos conceitos de modelagem temporal, primeiro porque são familiares a todas as pessoas e, mais significativamente, porque são extensões sonoras da ação humana; existe uma relação causal entre o ato de respirar ou o gesto físico e os consequentes perfis espectrais e dinâmicos. O efeito do condicionamento de longa duração resultou em um conjunto referencial de objetos sonoros auditivamente aceitáveis, que continuam a exercer influência tanto consciente quanto inconsciente na composição eletroacústica.

Durante a execução de uma nota, a entrada de energia é traduzida como alteraçóes na riqueza ou complexidade espectral. Quando ouvimos a nota, revertemos essa relação de causa e efeito deduzindo os fenômenos energéticos a partir das mudanças na riqueza espectral. O perfil dinâmico articula a mudança espectral: o conteúdo espectral responde a forças dinâmicas ou, inversamente, as forças dinâmicas são deduzidas a partir da mudança espectral. Essa congruência auditiva dos perfis espectrais e dinâmicos e sua associação com os fenômenos energéticos são a substância da prática perceptiva cotidiana. No ambiente, quando um som chega ao ouvinte, sua intensidade espectral e dinâmica aumenta a uma taxa proporcional à velocidade percebida. Além disso, o aumento da intensidade espectral permite que detalhes espectrais internos sejam revelados em função da proximidade espacial. Sons musicais estão indissociavelmente ligados a essa experiência da passagem do tempo interpretada por meio de mudanças no espaço espectral, mesmo quando os sons não estão realmente se movendo pelo espaço. Se esses fundamentos naturais da percepção sonora são ignorados na composição das morfologias, no processo de estruturação e na articulação espacial das estruturas, o ouvinte pode instintivamente detectar uma deficiência musical. A evolução da mudança espectral e dinâmica, portanto, trabalha dentro de tolerâncias naturalmente determinadas pela experiência auditiva. Trabalhar de maneira imaginativa com essas tolerâncias está no cerne das habilidades e do julgamento na composição eletroacústica, e a falta de apreciação de sua crucial importância muitas vezes explica a fraca resposta que os trabalhos eletroacústicos recebem. 
Podemos discernir três arquétipos morfológicos na origem dos sons instrumentais: o ataqueimpulso, o ataque-decaimento e a continuante formada (ver Figura 2). Seus perfis podem ser grafados usando símbolos. Cada símbolo descreve três fases temporais vinculadas: início, continuação e terminação. A dimensão vertical do símbolo representa a riqueza espectral e o nível dinâmico, que são considerados como congruentes.

O arquétipo de ataque ou impulso é modelado a partir de uma única nota destacada - um início repentino que é imediatamente encerrado. Neste caso, o início do ataque também é sua terminação.

O ataque com decaimento é modelado a partir de sons cujo início de ataque é estendido por uma ressonância (uma corda pinçada ou um sino, por exemplo) que decai rápida ou gradualmente até a sua extinção. $\mathrm{Na}$ Figura 2, o símbolo fechado representa o decaimento mais rápido, que é fortemente determinado pelo ataque. O símbolo de ataque aberto, com o símbolo de terminação separado, reflete um decaimento mais gradual, em que o ouvido se afasta da influência formativa do ataque e é conduzido para o comportamento continuado do som no seu caminho para a terminação. $\mathrm{Na}$ última versão da figura, tomamos consciência de um equilíbrio entre as três fases interligadas, enquanto o arquétipo ataque-impulso é totalmente ponderado em relação ao início.

O terceiro arquétipo é a continuante formada, que é modelada a partir de sons sustentados. $\mathrm{O}$ início é graduado, estabelecendo-se em uma fase contínua que eventualmente se conclui em uma terminação graduada. O início é percebido como uma influência muito menos formativa do que nos outros dois arquétipos. A atenção é voltada para a maneira como o som é mantido, e não para a sua iniciação.

FIGURA 2 - Arquétipos morfológicos

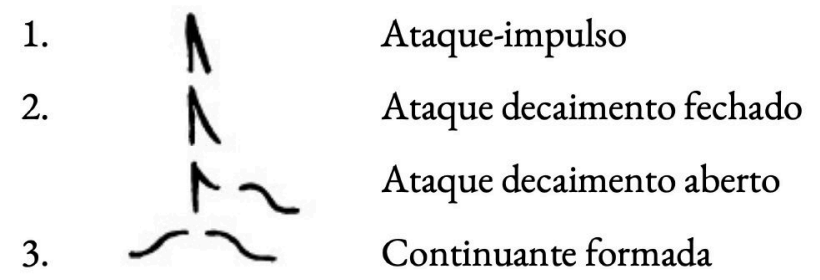

\footnotetext{
${ }^{8}$ Smalley prefere a palavra "continuante" ao invés de "continuação", para dar ao termo um caráter único, menos genérico. A continuante é dita “formada” por já ter atingido um determinado grau, como explicado adiante (N. de T.).
} 
A partir desses arquétipos centrais, uma ampla e sutil variedade de articulações temporais é gerada. Existe, por exemplo, uma grande diversidade de inícios entre um ataque nítido e um início graduado tentativo, e sabemos bem a complexidade das características do início, graças à prática da performance instrumental. De fato, essas características servem para identificar a personalidade de determinados intérpretes e o ouvido treinado provou ser sensível a mudanças espectrais detalhadas.

Partindo dos pontos de referência tradicionais, podemos estender os arquétipos em uma lista mais ampla de modelos morfológicos (ver Figura 3). Em primeiro lugar, é útil acrescentar um segundo tipo de continuante formada cujas fases de início e terminação são mais rápidas do que as do arquétipo: a continuante formada inchada. Em segundo lugar, incluímos inícios e decaimentos lineares. A linearidade perfeita é normalmente menos aceitável para o ouvido, pois pode parecer muito mecânica ou artificial; a linearidade absoluta é, portanto, mais frequente quando sintética do que quando natural. Por fim, apresentamos as versões reversas das fases de início (que não devem ser confundidas com a reversão literal dos sons na composição em fita). Terminações nem sempre são encerramentos silenciosos. Uma mudança de direção espectral e dinâmica durante a fase de continuação pode iniciar um aumento de tensão em direção à terminação. O contexto nos leva a acreditar que podemos estar entrando em um novo início. Assim, uma terminação pode também atuar como um início.

FIGURA 3 - Modelos morfológicos

arquétipo ataque-impulso
arquétipo ataque-decaimento fechado
forma reversa


Essa mudança de direção durante a fase de continuação das morfologias abertas introduz o conceito de correspondência, um ponto ou estágio no tempo em que ocorre uma alteração morfológica - uma espécie de modulação morfológica. Vamos elaborar um exemplo hipotético desse processo tomando o segundo arquétipo e expandindo-o para uma unidade estrutural. A atenção é imediatamente atraída pelo ataque na fase de início, cujo impacto põe em movimento um espectro ressonante que podemos esperar que decaia gradualmente. Quanto mais nos afastamos do momento do ataque, mais podemos ser persuadidos a observar como os componentes espectrais da fase de continuação se desenrolam, e menos interessados estaremos no papel genético do impacto inicial. Nesta fase, o compositor pode intervir no que, até agora, tem sido um processo natural, desenvolvendo e alterando o curso dos componentes espectrais. Através dessa intervenção, a expectativa de decaimento pode ser adiada, desviada ou evitada, alterando assim a orientação da estrutura. A consequente expansão espectral não pode continuar indefinidamente, e uma estratégia terminal será eventualmente invocada, seja para encerrar a estrutura ou fundi-la em outra estrutura.

Mas morfologias não são apenas objetos isolados. Elas podem ser vinculadas ou fundidas em cadeias para criar morfologias híbridas. A Figura 4 nos permite mostrar outras correspondências possíveis durante uma cadeia morfológica. As fases continuantes abertas permitem correspondências através de fusão, como percebemos no exemplo baseado no segundo arquétipo. Correspondências mescladas também podem ocorrer através do cruzamento (cross-fading) de fases de terminação e de início, ou mais rapidamente como consequência de uma terminação em início reverso. É claro que mudanças morfológicas também podem ocorrer através de interpolação.

FIGURA 4 - Encadeamentos morfológicos

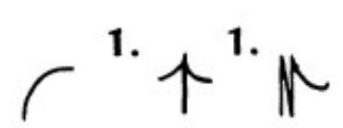

3.
1.

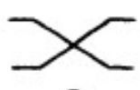

2.
1.

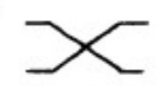

2.
1.

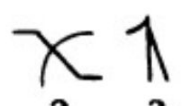

2. 3 .

\section{Fases continuantes abertas}

2. Correspondência por cruzamento

3. Terminaçóes em início reverso levando a novos inícios 
O encadeamento de ataques-impulsos cria circunstâncias perceptivas de consequências estruturais importantes. Comprimindo a distância entre os ataques-impulsos, entramos no continuum ataque-efluivio, uma equivalente temporal do continuum altura-eflúvio que vimos reunidas sob a tipologia espectral (ver Figura 5). Num dos extremos do continuum de ataques, a separação entre objetos ataque-impulso repetidos é preservada. O primeiro estágio da compactação cria iteração, na qual os ataques-impulsos interligados são percebidos como um objeto unificado. À medida que os ataques-impulsos vão se comprimindo, passamos da iteração à percepção do grão, em que os impulsos, antes individuais, perderam qualquer vestígio da sua identidade como separados. Um ato de compressão final expele qualquer característica granular.

FIGURA 5 - O continuum ataque-eflúvio

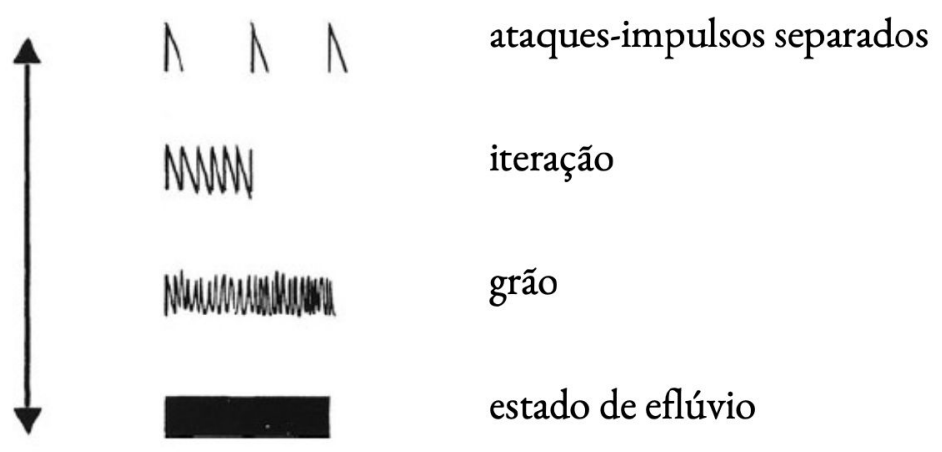

Movendo-se através do continuum, o ouvido eventualmente falha em distinguir os componentes antes separados, devendo, portanto, voltar sua atenção para as morfologias que moldam os trechos mais amplos do movimento estrutural. Assim, como no continuum altura-eflúvio, as circunstâncias de contexto conspiram para mudar o nível em que o ouvido consegue responder à estrutura musical. As consequências musicais do eflúvio de altura e do eflúvio de ataque são, portanto, as mesmas, embora os meios de se aproximar do estado de eflúvio sejam diferentes.

Já foi apontado, quando uma estrutura maior foi elaborada a partir do segundo arquétipo, que arquétipos e modelos morfológicos não estão confinados a dimensões semelhantes à nota. 
Podemos considerar o desenho da tensão referente à relação início-continuação-terminação como um reflexo de focos e funções estruturais de grande escala, e vice-versa. Desta maneira, as tensóes internas dos arquétipos morfológicos são projetadas em níveis estruturais mais altos: as tensões espectrais e dinâmicas inerentes às extensões sonoras do gesto são os fundamentos da estruturação musical. Voltaremos a examinar isso mais de perto quando as observações espectromorfológicas estiverem completas.

\section{Movimento}

Até agora, consideramos as morfologias principalmente em contornos espectrais e dinâmicos primitivos, aludindo a extensóes potenciais por meio de correspondência e encadeamento. Ao enfrentarmos a questão do movimento, começamos a penetrar nos meandros do design espectromorfológico. Tomamos como certo que música é movimento no tempo. Como resultado da música eletroacústica, tornamo-nos cada vez mais conscientes de uma extensa variedade de tipos e padrões de movimento. O movimento musical foi tornado mais aparente com o advento da estereofonia, a pesquisa contínua sobre localização espacial e a crescente sofisticação dos sistemas de difusão de alto-falantes, levando a um real movimento espacial. No entanto, ao controlar a modelagem espectral e dinâmica, o design espectromorfológico, por si só, cria movimentos reais e imaginários sem a necessidade do movimento real no espaço. 
FIGURA 6 - Tipologia do movimento

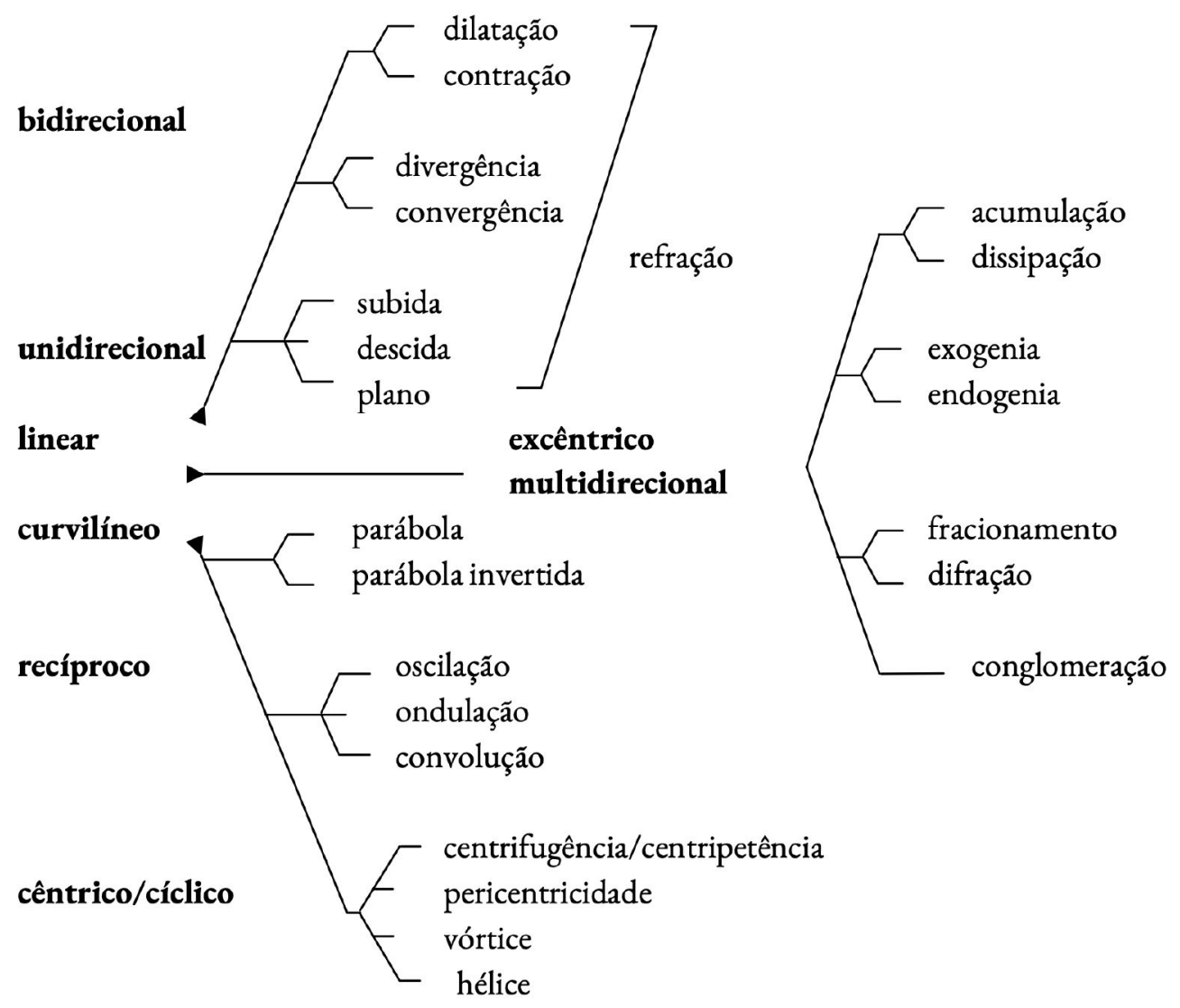

A tipologia do movimento está apresentada na Figura 6. Não é sugerido que o movimento musical, que pode ser um amálgama complexo de vários tipos, tendências, ambiguidades e contradiçôes, deva sempre se encaixar perfeitamente em uma das categorias tabuladas. Entretanto, as cinco analogias básicas de movimento representam uma série de possibilidades: unidirecional, bidirecional, recíproco, cêntrico/ciclico e excêntrico/multidirecional.

As categorias de movimento podem ser aplicadas a vários níveis estruturais e escalas de tempo, desde a forma de um breve objeto sonoro até o movimento de uma grande estrutura, de grupamentos de objetos a grupamentos de estruturas maiores. Uma categoria de movimento pode se referir ao contorno externo de um gesto, ou ao comportamento interno de uma textura. Imaginemos, por exemplo, uma estrutura cuja forma externa segue um caminho divergente, mas cuja padronização interna é composta de partículas que gradualmente se aglomeram, ou uma estrutura em acumulação cujos componentes internos são pequenos objetos parabólicos. 
Todos os tipos de movimento têm suas próprias orientações. O movimento sempre implica uma direção, por mais aberta, limitada, ambígua, mínima ou complexa que possa ser uma implicação, ou simultâneas implicações. Por exemplo, uma subida linear sustentada é sugestiva porque a linha não pode continuar indefinidamente. Ela pode desaparecer no esquecimento, pode atingir um teto estável, pode atingir um objetivo, ou seu movimento implícito pode ser interrompido ou extirpado por um novo evento. A modelagem espectromorfológica e o contexto musical fornecerão pistas para uma implicação ou implicações. Em outras palavras, a composição espectromorfológica, assim como outras linguagens musicais, preocupa-se com expectativas realizadas e frustradas, e tais expectativas são baseadas em experiências perceptivas compartilhadas. O fracasso em entender as implicações direcionais e o andamento temporal do movimento é um problema comum na composição.

A parte superior da tabela da tipologia do movimento expande o princípio linear simples. As categorias lineares são autoexplicativas, com exceção de dilatação e contração, que permanecem lineares apenas de uma maneira muito generalizada. Podemos considerá-las como traduçóes livres de divergência e convergência. $\mathrm{Na}$ sua forma mais rebelde, elas podem ser pensadas como movimentos excêntricos. A incorporação da refração nos lembra que o movimento linear pode ser desviado de seu curso, resultando em uma mudança de ângulo ou de direção. Isso pode significar que o movimento linear transforma-se em movimento curvilíneo, particularmente porque uma deflexão pode ser interpretada como uma mudança na velocidade e, portanto, será traduzida em termos exponenciais. Então, as distinções lineares e curvilíneas não são tão claras.

O movimento curvilineo liga três fases: subida-pico-descida ou sua inversão descida-valesubida. A curvatura do movimento é totalmente reciproca se o movimento em uma direção é equilibrado pela reciprocidade na direção oposta. É comum a reciprocidade parcial, em que a terceira e a primeira fases têm comprimentos diferentes. Os perfis dinâmicos e espectrais, sejam separadamente ou em colaboração, ajudam a articular uma variedade de formas curvilíneas associadas a mudanças na velocidade. Por exemplo, uma variedade de movimentos lançados ou saltados é alcançada por variaçóes apropriadas nas taxas e distâncias de subida e descida, por um perfil morfológico associado em ida e volta ao pico ou vale, e por uma cuidadosa proporção do tempo que será necessário para efetuar a mudança de direção. Finalmente, parece que um som 
sustentado que muda de direção é percebido como curvilíneo. Para que uma mudança de direção seja percebida como linear, o movimento e sua taxa devem ser interrompidos ou acentuados no pico ou no vale, para criar a impressão de uma mudança de direção angular.

Oscilação, ondulação e convolução são extensões do movimento curvilíneo. Oscilação descreve a alternância curvilínea entre dois pontos; ondulação implica formas de dimensões variadas traçando movimentos recíprocos; convolução implica um complexo entrelaçamento de formas de movimento recíproco.

O foco em um ponto central de referência está implícito nos movimentos cêntricos, tanto irradiando de um centro quanto convergindo para ele. Isso não significa que um ponto central precise ser representado por um som real, apenas que presumimos a existência de um foco central depreendido das tendências de movimentos circundantes. Em termos visuais, o movimento centrípeto é comum. Mas a música, por ser pensada em termos temporais e condicionada pela prática de notação, move-se por estágios sucessivos no tempo, da esquerda para a direita, parecendo assim proibir qualquer analogia com a nossa varredura visual, que pode se deslocar para frente e para trás de um objeto em movimento. A solução musical repousa na natureza cíclica dos movimentos cêntricos relacionados à memória de curto prazo. A reciclagem do movimento nos permite voltar-a-perceber e, portanto, incutir sua forma giratória e sua continuidade em uma série de quadros semelhantes aos de um filme, e supor a centralidade como resultado. Isso pressupóe que os contornos e elementos morfológicos conspiram o suficiente para criar uma impressão central, antes de mais nada. Um projeto morfológico cuidadoso, auxiliado pela articulação espacial, pode produzir resultados muito efetivos.

Nem sempre é fácil vincular um movimento centralizado a um tipo muito específico. Os cinco termos cêntricos sugerem possíveis matizes interpretativos. Movimento centrífugo expressa sons que voam do centro, enquanto o movimento centripeto tende para ele; movimento pericentral significa movimento ao redor de um centro; movimento em vórtice (turbilhão) descreve o movimento de partículas em torno de um eixo; o movimento helicoidal, que segue um formato em espiral, implica aceleração ou desaceleração e alterações nas dimensões durante a sucessão de ciclos (reciclagem). Finalmente, ciclos sucessivos não precisam ser repetiçốes exatas. Os componentes e o andamento podem variar sem destruir o foco central. 
Movimento excêntrico sugere uma falta de foco central, mas ambiguidades ainda são possíveis. O movimento cêntrico pode ser construído de modo a incorporar elementos de excentricidade, assim como no movimento excêntrico os princípios cêntricos podem não estar totalmente ausentes, embora o processo de movimento seja tal que os movimentos cêntricos não dominem. $\mathrm{O}$ termo complementar 'multidirecional' serve para enfatizar a expansão da ideia linear via divergência e convergência que, como notamos, pode ser desenvolvida em direção à excentricidade.

Movimento exógeno descreve crescimento por adiçóes ao exterior de um som, enquanto endogenia denota um crescimento de dentro. O primeiro implica um ponto de referência inicial, enquanto o segundo implica um quadro cujo espaço intermediário torna-se cada vez mais ativo ou denso. Ambos os processos podem funcionar de maneira inversa, e são categorias específicas de acumulação, um termo muito geral, comum tanto como movimento quanto como processo de estruturação. Dissipaçãa é o seu oposto. O fracionamento descreve uma divisão em fragmentos menores, enquanto a difração implica a divisão em uma configuração de faixas sonoras. A conglomeração expressa o processo inverso, a formação de uma massa ou objeto compacto a partir de fragmentos ou faixas. Todos esses termos podem estar relacionados a processos de decomposição espectral. Ao contrário de outros grupos de movimentos, estes são processos de crescimento que envolvem transformações texturais, cujo resultado morfológico é radicalmente diferente do estado inicial.

A Figura 7 amplifica detalhes internos da tipologia de movimento que chamamos de estilo de movimento. À esquerda do diagrama, estão os quatro contínuos básicos que delineiam os limites influenciadores do progresso interno do movimento: se objetos, componentes ou eventos simultâneos atuam juntos ou independentemente, se o movimento ocorre ou não em um fluxo contínuo, se o contorno é graduado de maneira uniforme ou não uniforme, e se a mudança de movimento é regular ou não.

O trio central de termos identifica três categorias típicas de design de movimento interno, texturas que podem ser constituídas por um único tipo morfológico (monomorfológicas) ou uma mistura de morfologias (polimorfológicas). 
FIGURA 7 - Estilos de movimento

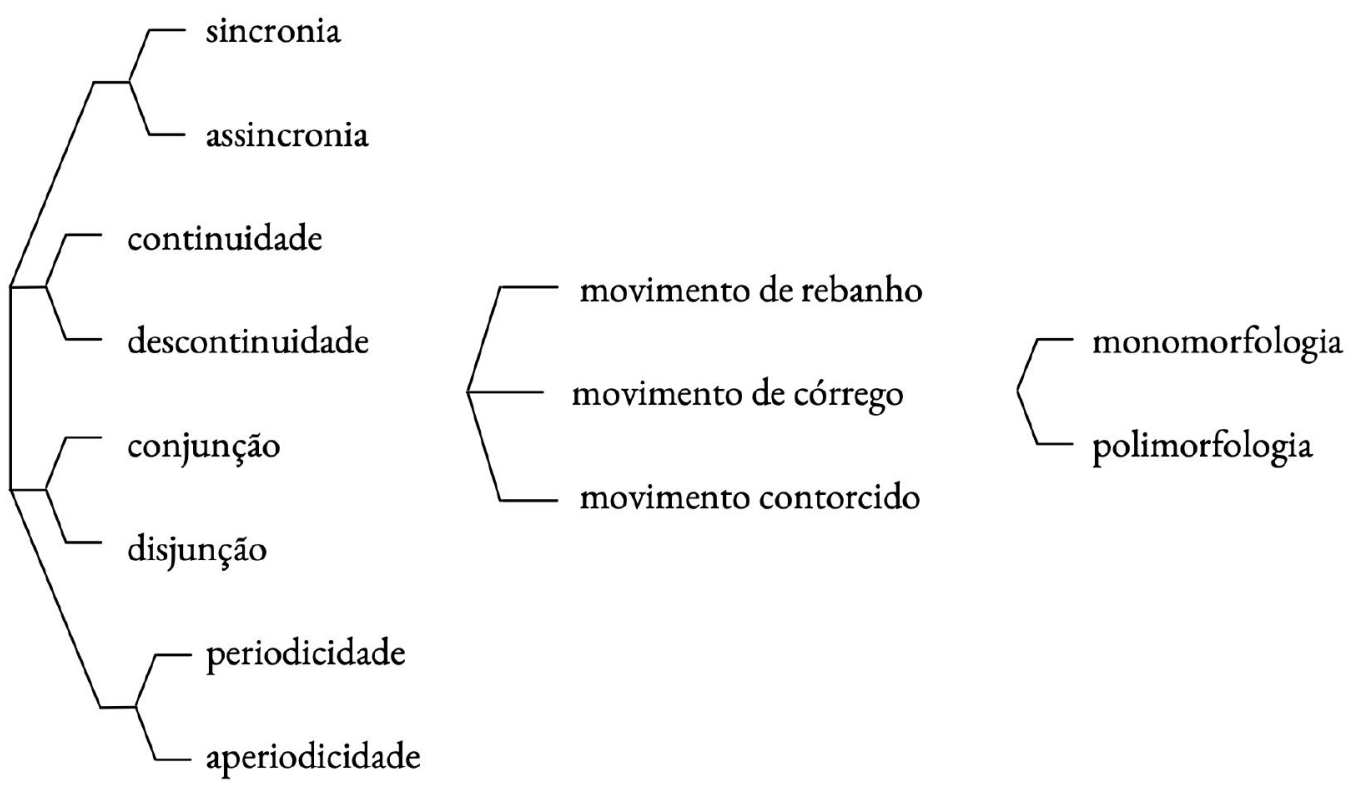

No movimento de rebanho, os componentes individuais comportam-se em um grupo ou grupos coerentes. O conjunto, portanto, pode ser apenas monomorfológico, mas o ouvido segue o comportamento de rebanho, e não seus componentes individuais. Quanto menor a densidade ou mais lento o movimento, maior a probabilidade de os componentes individuais se destacarem. Se o comportamento de rebanho se tornar mais difuso ou menos denso, começamos a percorrer o continuum ataque-eflúvio ou o continuum altura-eflúvio, eventualmente acabando por destruir o conjunto. O movimento de rebanho, portanto, ocupa o meio-termo focal entre individualidade e aniquilação.

O movimento de córrego contém um fluxo simultâneo de movimentos que mantêm, cada um, sua própria identidade. Isso pode ocorrer por várias razóes: os veios correntes podem ser morfologicamente diferentes ou possuir familiares similaridades apenas diferentes o bastante para diferenciá-los; eles podem entrar em contraste pelo tipo de movimento; eles podem ser separados por lacunas de textura para formar estratos, mas não precisam se mover em paralelo. Também são possíveis os córregos em rebanho (ou rebanhos de córregos, dependendo de qual é o fator mais dominante). Podemos refinar ainda mais a qualificação dos movimentos de córrego ao estudá-los com base nos quatro contínuos básicos, nos quais encontramos possibilidades de potenciais relações coincidentes entre veios correntes - por meio de periodicidade ou sincronicidade, por 
exemplo. Por fim, é extremamente difícil que uma identidade em separado seja absoluta, uma vez que associamos imediatamente os veios correntes por meio de sua simultaneidade, mesmo que seu padrão ou seu comportamento possam ser drasticamente diferentes. Córrego em fluxo é, portanto, uma marca de contraponto.

Contorção sugere uma relação entre componentes tão emaranhados que precisam ser considerados como um todo. Mesmo que os componentes individuais possam se destacar ao ouvido, eles estão presos por uma desordem ao seu redor que impede o movimento de córrego, e seus contornos irregulares e sobrepostos resistem ao movimento de rebanho. A natureza do caos domina seus participantes. A contorção ou é polimorfológica, ou então os componentes são morfologicamente relacionados, mas suficientemente flexíveis, ou ainda extremos o bastante em suas diferenças para permitir uma organização contorcida. Existe certa ordem na desordem, e o movimento contorcido cria sua coerência através de uma similaridade de comportamento errático compartilhado por seus componentes, quaisquer que sejam suas diferenças de personalidade.

Os critérios acima dizem respeito ao movimento interno da textura espectral. Precisamos também considerar contextos texturais mais estáveis. Na Figura 8, existem quatro texturas básicas de referência, chamadas configuraçóes estáveis do espaço de alturas. A tessitura deve ser linear e consistente, mas a estabilidade não requer necessariamente consistência interna de movimento. Quando se deixa o movimento descontínuo ou aperiódico se alongar por tempo suficiente, ele também pode fornecer configurações estáveis caso o ouvido venha a aceitar a existência contínua do movimento, ao invés de ser atraído por suas variações internas. Movimentos recíprocos e centrados, quando padronizados de modo consistente, também podem fornecer estabilidade. Mas a palavrachave é 'configuração', pois implica que outros eventos podem florescer dentro do espaço das alturas. A configuração fornece o ponto de referência ou os limites de um ambiente no espaço das alturas. Se eventos novos ou alternativos são introduzidos, nosso ouvido é atraído para eles e começamos a tomar a configuração como garantida, colocando-a em segundo plano. Esse relacionamento, é claro, está aberto a variações consideráveis de jogo de focos. 
FIGURA 8 - Configurações estáveis do espaço de alturas

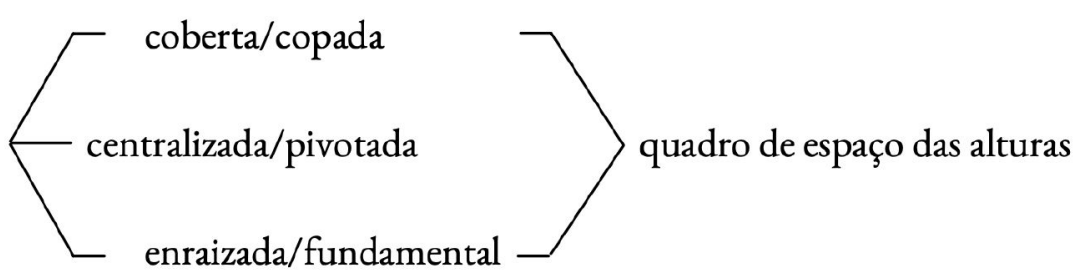

Numa configuração de cobertura (copa), a atividade musical ocorre numa área de alturas agudas. Essa atividade pode ser independente $\mathrm{da}$ cobertura, suspensa nela ou espectromorfologicamente ligada a ela.

Seu oposto é a configuração enraizada, à qual os mesmos comentários se aplicam. Mas a configuração enraizada também tem as conotações tradicionais dos pontos pedais, que continuaram presentes na música eletroacústica sob o disfarce de drones. Assim, pode haver associações com a ideia de um tom fundamental, a partir do qual o movimento espectral se desenvolve. Este é o exemplo clássico de permanência de uma base de notas sendo tomada como certa enquanto o ouvido segue as variaçóes espectrais acima da raiz.

A copa e a raiz, juntas, formam um quadro de espaço de alturas. Tal formação polar estabelece limites que podem convidar analogias com a experiência das dimensões e grandeza do espaço visual.

Por fim, existe a configuração centralizada ou pivotada, que fornece uma referência central em torno da qual eventos musicais surgem, de onde eventos florescem, para a qual os eventos gravitam. As conexões com os movimentos cêntricos são claras, mas seu papel central, principalmente se for baseado em notas, pode significar que existe menos conteúdo a ser relegado a segundo plano e, portanto, é provável que passe ao primeiro plano.

Agora, cobrimos os recursos básicos do projeto espectromorfológico, expandindo as noçôes de tipologia espectral para morfologias, tipologia de movimento, estilo de movimento e configuraçôes estáveis de espaço de alturas, que inevitavelmente introduziram a ideia de textura espectral: a distribuição vertical de componentes ou partes constituintes do espaço das alturas. Percebemos que a fusão e a difusão (ou dispersão) são noções importantes que afetam nossa 
percepção da textura espectral. Podemos preferir pensar em termos de opacidade e transparência texturais. A opacidade é um estado em que os critérios eflúvicos bloqueiam os detalhes, enquanto a transparência abre interstícios texturais que permitem uma impressão de clareza espacial. Podemos pensar em componentes como se eles estivessem ocupando certos locais dentro de limites do espaço de alturas, em cada um desses locais como tendo uma dada dimensão, e na textura espectral como sendo talvez ponderada em favor de um ou mais locais, às custas de outros. A ideia de ponderação espectral chama a atenção para o foco atribuído a um componente ou a um grupo componente, em particular. Uma complexa interação de fatores pode influenciar essa ponderação: tipo espectral, morfologia, proeminência dinâmica, se o componente está imprensado entre lacunas de textura, as dimensões desses interstícios - em resumo, quaisquer fatores contextuais ajudam no diagnóstico de uma identidade particular.

\section{Processos de estruturação}

Nivel e foco

$\mathrm{Na}$ música espectromorfológica, não existe uma unidade de nível primário consistente e, portanto, também não há nela equivalente simples para a estrutura da música tonal, com sua estratificação hierárquica da nota para cima, passando pelo motivo, pela frase, pelo período, até chegarmos a abranger a peça na sua totalidade. Unidades significativas no nível mais básico da estrutura podem ter dimensões temporais consideráveis, como sugerimos na discussão sobre o movimento. Mas, muitas vezes, é difícil ou mesmo impossível perceber uma 'unidade' ou um 'objeto' autocontido, particularmente em contextos musicais contínuos que prosperam em morfologias e movimentos intimamente interligados. Não existe sequer um referente de densidade consistente, um pulso que defina o andar através do qual começamos a apreender uma obra ou um 'movimento' de uma obra. De fato, o aumento da flexibilidade temporal é um dos bônus da experiência musical que foram recentemente desenvolvidos. Temos que ter mais preparo para variar o andamento e a intensidade de nossa audição, de acordo com os cambiantes indícios espectromorfológicos, descobertos à medida que o movimento se desenrola. 
Podemos até não conseguir detectar relações hierárquicas permanentes ao longo de uma obra, mas exigimos que uma estrutura seja multinivelada: precisamos que nos seja oferecida a possibilidade de variar nosso foco perceptivo por toda uma série de níveis durante o processo de escuta. De fato, uma obra deve possuir esse potencial focal se quiser sobreviver a repetidas escutas, durante as quais buscamos não apenas as recompensas da escuta anterior, mas também novas revelaçôes. Mesmo que não possamos encontrar relacionamentos hierárquicos permanentes por toda uma obra, ainda assim iremos frequentemente descobrir hierarquias fraturadas de diversas dimensões temporais e variado número de estratos, à medida que nossos ouvidos examinam a estrutura.

Uma razão crucial para muitos trabalhos eletroacústicos falharem pode ser a inabilidade do compositor de manter o controle sobre a varredura focal dos níveis estruturais durante o processo de composição. Particularmente na composição em fita, devido à necessidade de constante repetição dos sons durante o processo de aprimoramento, o compositor é facilmente enganado na percepção de detalhes microscópicos que o ouvinte nem vai perceber. Além disso, a repetição constante rapidamente mata o frescor de um som, de modo que a avaliação do material pelo compositor vai se cansando. Por outro lado, uma concentração excessiva no design dos níveis mais altos da estrutura pode facilmente levar a um trabalho com falta de detalhes no nível inferior, detalhes estes altamente necessários para recompensar repetidas audições. Assim, um trabalho com foco extremo e consistente nos níveis estruturais mais altos cairá rapidamente em uma redundância auditiva, enquanto um trabalho concebido de maneira míope, com foco exclusivamente nos níveis inferiores, será entendido como carente de catolicidade estrutural.

Embora esses problemas não sejam uma prerrogativa exclusiva da composição eletroacústica, eles alcançam um novo significado neste meio, primeiro porque o compositor tem o ônus adicional de encontrar ou criar materiais a partir do zero e, em segundo lugar, porque a intervenção da tecnologia pode se tornar tão facilmente um obstáculo quanto uma ajuda, junto com os problemas de projetá-la e usá-la como um fim em si mesma, ao invés de usá-la a serviço da música.

Voltamos, então, à discriminação auditiva e à percepção como as ferramentas musicais supremas. Não é um conhecimento científico que é necessário, mas um conhecimento fundado na experiência. A compositora ou compositor deve superar todas as preocupações e distraçóes do 
processo de fabricação para se tornar o sujeito de sua própria experimentação musical - o ouvinte universal, o substituto de todos os ouvintes.

\section{Gesto e textura}

Os termos gesto e textura ${ }^{9}$ aqui representam duas estratégias estruturantes fundamentais associadas ao foco multinível e à experiência do desdobramento temporal da estrutura. Já estamos familiarizados com a posição especial atribuída à ideia de gesto como um elo quase tangível com a atividade humana, mas mesmo que tenhamos nos referido a textura e textura espectral ao discutirmos movimento ainda temos que definir totalmente o termo.

Gesto diz respeito à ação direcionada a partir de uma meta anterior ou em direção a um novo objetivo; relaciona-se com a aplicação de energia e suas consequências; é sinônimo de intervenção, crescimento e progresso, e está casado com a causalidade. Se não sabemos o que causou o gesto, pelo menos podemos supor, a partir de seu perfil energético, o que poderia tê-lo causado, e também sua espectromorfologia fornecerá evidências da natureza de tal causa. A causalidade, real ou presumida, está relacionada não apenas com a intervenção física da respiração, mão ou dedos, mas também com eventos naturais ou projetados, análogos visuais, experiências psicológicas sentidas ou mediadas pela linguagem ou paralinguagem - de fato, qualquer ocorrência que pareça provocar uma consequência, ou consequência que parece ter sido provocada por uma ocorrência.

A textura, por outro lado, preocupa-se com os padróes internos de comportamento, energia direcionada para o interior ou reinjetada, autopropagada; uma vez instigada, é aparentemente deixada por conta própria; em vez de ser provocada a agir, ela simplesmente continua se comportando. Onde o gesto é intervencionista, a textura é laissez-faire ${ }^{10}$; onde o gesto se ocupa do crescimento e progresso, a textura se extasia na contemplação; onde o gesto pressiona para adiante, a

\footnotetext{
${ }^{9}$ As qualidades aqui atribuídas aos termos 'gesto' e 'textura' podem ser encontradas numa variedade de textos, embora nem sempre pensadas com clareza. Conceitos associados a Stockhausen, como 'gestalt', 'estrutura', 'estase' e 'processo' são próximos, embora confusos (HEIKINHEIMO, 1972, p. 139). Boulez se refere a 'gesto' e 'contemplação' em relação à apresentação da sua peça "Eclat", na fita-cassete Le temps musical 1 (1978). Harvey (1984, p. 83-86) discute 'contemplação'.

${ }^{10} \mathrm{O}$ autor utiliza a expressão em francês ligada ao liberalismo econômico que significa, literalmente, deixar fazer. Figurativamente, conota "deixar acontecer", sem interferências (N. de T.).
} 
textura marca o tempo; onde o gesto é carregado pela forma exterior, a textura se volta para a atividade interna; onde o gesto incentiva o foco no nível superior, a textura incentiva o foco no nível inferior. A textura encontra suas causas e conexões em todas as atividades afins experimentadas ou observadas como parte da existência humana.

Claro, tudo isso é muito simples, mas antes de perturbar a simplicidade, faremos uma digressão para considerar os mecanismos pelos quais gesto musical e textura ligam-se às suas fontes.

Vamos considerar os instrumentos musicais e seus gestos sonoros como substitutos para gestos não musicais. Esta é a substituição de primeira ordem ${ }^{11}$, a competência tradicional da música instrumental. Se essa fonte instrumental é transformada eletroacusticamente, mas retém o suficiente de sua identidade original, ela permanece como uma substituta de primeira ordem. Através da síntese sonora e de processamento de sinal mais drástico, a música eletroacústica criou a possibilidade de uma substituição de segunda ordem, nova, na qual o gesto é presumido a partir do perfil energético, mas uma causa instrumental real não pode ser reconhecida e não existe. Ela não pode ser verificada olhando-se para a causa. A substituição de segunda ordem, portanto, mantém seus vínculos humanos apenas pelo som, e não pelo uso de um instrumento que seja uma extensão do corpo. Além dessa segunda ordem, abordamos agora a substituição remota, em que os vínculos com uma causalidade presumida são progressivamente abrandados, de forma que a causa física não pode ser deduzida e nós, assim, entramos sozinhos no reino da interpretação psicológica. O nosso período histórico é, portanto, o único em que substituiçôes de segunda ordem e substituiçôes remotas deslocaram o peso da escuta para além da fisicalidade direta. Ironicamente, porém, é também o período em que as fontes de base física ganham importância cada vez maior, uma vez que os compositores de gravações de campo têm acesso direto a atividades sonoras antes não acessíveis como materiais musicais. Assim, pela primeira vez, também viajamos de volta da substituição de primeira ordem para explorar fontes não instrumentais. Portanto, temos acesso direto ao gesto, incluindo uma variedade de gestos vocais não aceitos anteriormente como materiais musicais.

Embora estejamos cientes da textura nas composições musicais, a textura como uma

\footnotetext{
${ }^{11}$ Originalmente, Smalley utilizou a palavra em inglês surrogacy, que significa barriga de aluguel. Em comunicação pessoal, comentou: "Quando usei o termo pela primeira vez (na década de 1980), a noção de barriga de aluguel era uma questão. E o termo pretendia evocar essa referência. Foi usado também para designar bispos substitutos - substituindo bispos! Basicamente, é alguém que representa outra pessoa, ou seja, um substituto”. (N. de T.)
} 
característica da estruturação espectromorfológica é mais influenciada por texturas encontradas nos sons ambientais, pela ampliação dos detalhes internos da textura revelados pela gravação sonora, e também pela observação visual de texturas em fenômenos tanto animados quanto inanimados, sejam naturais ou artificiais. Enquanto o gesto tem suas origens inteiramente no corpo humano, a textura pode estar baseada tanto nos detalhes espectromorfológicos encontrados na substituição de primeira ordem do gesto quanto em objetos e fenômenos independentes do corpo humano.

Existem limites para a substituição? Existe um estágio em que o deslocamento da experiência torna-se intolerável? Nossas observaçôes sobre as tolerâncias do projeto espectromorfológico, as implicaçóes do andamento do movimento e o foco multinível são todos sintomas de uma substituição deslocada, inviável. Muitos dos problemas do ouvinte podem estar relacionados à perda de tangibilidade criada pelo rompimento dos laços gestuais diretos, ou às dificuldades em compreender o caráter remoto de uma nova substituição.

A relação entre gesto e textura é mais de colaboração do que de antítese. Gesto e textura geralmente compartilham a carga de trabalho estrutural, mas nem sempre com espírito igualitário. Portanto, podemos nos referir às estruturas como conduzidas pelo gesto ou como conduzidas pela textura, dependendo de qual é o parceiro mais dominante.

Num contexto conduzido pelo gesto, é este que domina. Se o gesto for fortemente direcionado e se mover rapidamente, é mais provável que o ouvido siga o ímpeto gerado, ao invés de insistir em quaisquer sutilezas texturais no interior do gesto. Com um gesto menos impetuoso, podemos imaginar a possibilidade de uma atração para detalhes internos da textura, o que criaria certo equilíbrio entre gesto e textura. $\mathrm{O}$ ouvido reconhece que um gesto está em marcha: o senso de movimento direcionado permanece e pode ser temporariamente dado como certo, enquanto o ouvido altera o foco para mergulhar no movimento textural, talvez para emergir novamente assim que um senso mais urgente de movimento direcionado for detectado. Podemos considerar essas circunstâncias como um exemplo de enquadramento de gestos.

Quanto mais o gesto é estendido no tempo, mais o ouvido é atraído para a expectativa do foco textural. O equilíbrio se inclina a favor da textura à medida que o ouvido se distancia das memórias de causalidade e é protegido dos desejos de resolução, enquanto se volta para dentro, para contemplar os critérios da textura. Eventos ou objetos gestuais podem ser facilmente introduzidos 
em texturas ou surgir delas. Este seria um exemplo de configuração de texturas, em que a textura fornece o ambiente para atividades gestuais.

Tanto o enquadramento de gestos quanto a configuração de texturas são casos de um equilíbrio capaz de ser inclinado em qualquer direção pelo ouvido. Eles indicam, mais uma vez, áreas de limites de tolerância, ambiguidades abertas à dupla interpretação e cruzamentos perceptivos (cross-fadings) que dependem da atitude de escuta. No geral, a atividade gestual é mais facilmente apreendida e lembrada por causa do caráter compacto de sua coerência. A apreciação da textura requer um escaneamento aural mais ativo e é, portanto, uma arte auditiva mais evasiva. Finalmente, não devemos esquecer que as tolerâncias de ataque-eflúvio e de altura-eflúvio são críticas para determinar o potencial de apreensão gestual ou textural.

\section{Funçôes estruturais}

Retomamos, agora, as três fases temporais interligadas do projeto morfológico - início, continuação e terminação - como modelos para as funçôes estruturais. Desta maneira, projetamos o desenho morfológico no desenho estrutural, revelando assim a ligação entre os níveis baixos e altos da estrutura. Na discussão sobre gesto e textura, já atribuímos quase inconscientemente essas funçôes de base morfológica. No movimento direcionado do gesto, a continuidade das três fases temporais estava em evidência, ou melhor, enfatizava ação direcionada para longe do início e ação direcionada para um término ou segundo início. A textura, por outro lado, é baseada no modelo de continuação.

A Figura 9 mostra como as três fases temporais podem ser expandidas para significar funçôes estruturais em níveis mais altos. As funçôes são reunidas em três grupos, cada um deles cobrindo uma série de termos com atributos em comum. Sem dúvida, os termos podem ser expandidos para incorporar diferentes nuances de significados adequados à sua própria interpretação das circunstâncias funcionais. 
FIGURA 9 - Funções estruturais

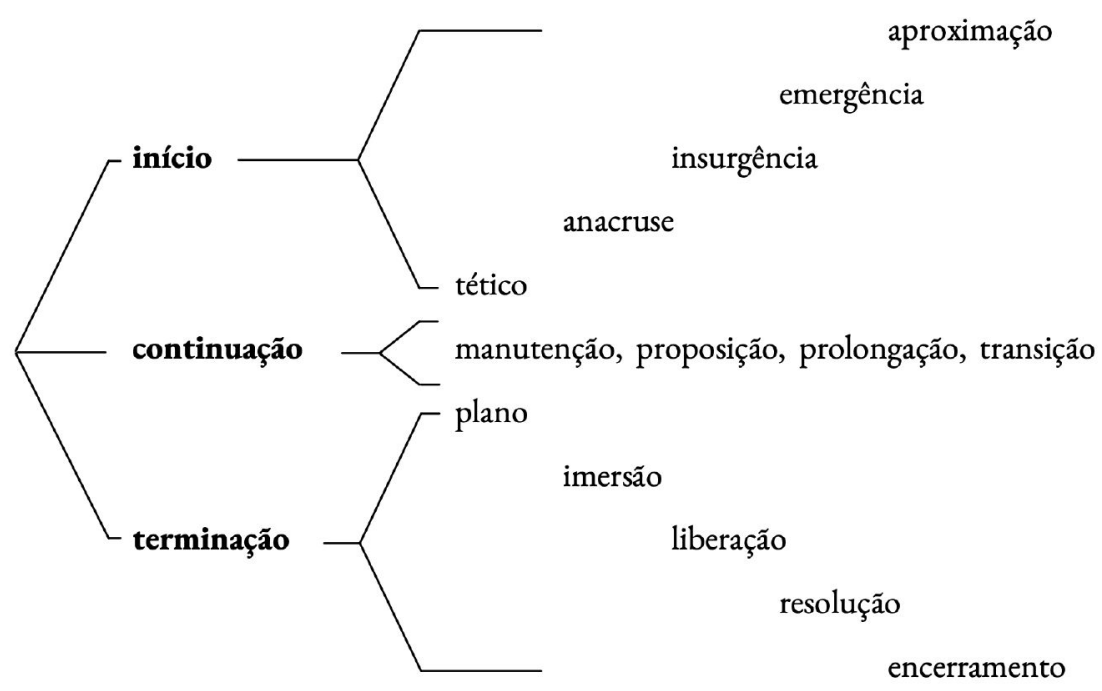

O grupamento inicio abrange uma série de possibilidades, desde tético e anacruse, mais específicos e tradicionais, até surgimento e aproximação, menos específicos. O grupamento continuação inclui uma ampla variedade, conforme seja benéfico à ambivalência de seu status: o termo manutenção é bastante sem comprometimento, apenas indicando a continuação daquilo que foi colocado em curso; proposição é mais definitiva e autoimportante, lembrando-nos da tradicional ‘exposição’; prolongação expressa o alongamento funcional, uma tocaia para uma continuidade mais definida; e transiçãa descreve o estágio intermediário entre outras funções supostamente mais importantes. Portanto, percebemos que a função continuação não é neutra: o tempo não pode parar e a verdadeira estase não é possível. No grupamento terminação, plano é o mais ambíguo. Um plano é sentido como uma zona de chegada ou uma lacuna, um estado relativamente estável, interpretado como uma meta do que veio antes. Os termos restantes têm suas contrapartes no grupamento início, exceto pela inexpressiva palavra encerramento.

Podemos atribuir funções em vários níveis estruturais, dependendo do eventual foco auditivo e do estágio alcançado no desvelamento da estrutura total. Para começar, nossa interpretação da função estrutural funcionará em uma escala local, mas à medida que a música avança, mais vai se revelando, de modo que, inevitavelmente, interpretamos as funções no contexto de circunstâncias mais regionais. Quando o trabalho está concluído, temos a oportunidade de reavaliar sua estrutura à luz da nossa experiência do todo. A atribuição de função estrutural como resultado de interpretações de curto alcance pode tornar-se inválida quando o contexto mais amplo for revelado. 
Além disso, uma superposição de funções relacionadas a diferentes dimensões temporais ocorre porque a atribuição funcional é realizada em todos os níveis da estrutura. Por exemplo, um objeto localizado pode ser parte de um grupo maior ao qual é atribuída uma função regional diferente. Uma vez que se tem a experiência da região como parte de um grupo maior, uma terceira atribuição pode ser conferida a este contexto mais global. A atribuição de funções estruturais é, portanto, um jogo hierárquico ou, mais precisamente, um processo multinível. Assim, durante a passagem do presente, estamos sempre ponderando, alterando e sobrepondo nossas interpretaçóes sobre as funções. O que interpretamos depende da nossa acuidade aural, do quão boa é a nossa memória auditiva, de como decidimos conscientemente ou inconscientemente focar a varredura do nosso ouvido e, é claro, da habilidade com que a compositora ou o compositor preparou a estrutura musical para nossa apreensão.

No entanto, a interpretação da função não é necessariamente um processo decisivo. Ouvintes e estruturas prosperam em ambiguidades. Durante o ato de escuta, mais de uma função pode ser atribuída simultaneamente a um único nível de atividade musical. Estas são atribuições interinas, sujeitas a confirmação ou alteração depois que o presente tenha passado e as implicações musicais tenham sido realizadas ou frustradas. Mas uma atribuição única e definitiva não é necessária, assim como nem sempre é possível, em particular se a estruturação envolve movimento contínuo e entrecruzamento estreito de eventos. A insegurança faz parte do processo musical e podemos ficar muito felizes por ter duplas ou até múltiplas atribuiçôes, as quais refletem nossa experiência de ambiguidades funcionais.

Vamos simular o processo interpretativo, seguindo duas sequências de cadeias de funçôes hipotéticas que podem ocorrer no curso de um trabalho:

anacruse $\rightarrow$ proposição?/prolongação?/transição?/plano? = plano = encerramento

Essa estrutura começa com uma anacruse e passa para a fase de continuação, que solicita uma série de questionamentos funcionais. Será esta uma proposição importante de um material significativo? Será apenas uma prolongação da anacruse? Será que estamos entrando em um estágio de transição, ou estaremos experimentando uma função planar, à medida que a fase de continuação 
é prolongada? Finalmente, atribuímos uma função planar que descobrimos estar colaborando com uma função de encerramento. Acabamos escolhendo o 'encerramento' mais neutro, porque estamos um pouco insatisfeitos com o comprometimento da fase de terminação e esperamos que esta não seja a terminação final do trabalho.

O segundo exemplo ocorre em três etapas:

\section{1. iniciação/proposição? = iniciação/proposição}

2. proposição $=$ plano $/$ transição? $=$ transição

3. transição $\rightarrow$ encerramento? = imersão/insurgência/surgimento

O começo da estrutura (a iniciação do início) e a proposição da continuação são duplas atribuições. Logo no primeiro momento, diagnosticamos a importância estrutural da função de proposição. À medida que a proposição segue, começamos a investir nas qualidades tanto planares quanto transitórias do contexto, mas finalmente nos contentamos com a transição, que supomos estar rumo ao encerramento. Mas o encerramento acaba sendo a imersão mais comprometida, ocorrendo simultaneamente com duas funçôes de início: uma insurgência, mais impetuosa, e um surgimento, mais cuidadoso. Eventualmente, portanto, preferimos não separar as funções entrelaçadas de iniciação, proposição e transição, e de maneira alguma podemos separar a tripla imersão, insurgência e surgimento. Não há tempo para um real sentimento de resolução, e qualquer aparência de terminação é negada pelos inícios sobrepostos.

Cada função não tem o mesmo significado. Deve haver uma variedade de ponderaçôes de funçôes em uma estrutura musical para criar um equilíbrio satisfatório das tensões temporais. A repetição excessiva da mesma configuração de funções, por exemplo, cotejará uma rápida indiferença auditiva, mesmo se o andamento for variado, simplesmente porque o tensionamento do padrão é muito previsível. Podemos também nos lançar a obras tão hesitantemente articuladas que dificilmente funções podem lhes ser atribuídas, ou nas quais ambiguidades aparentemente intermináveis induzem à paralisia psicológica. Existem trabalhos tão preocupados com as articulações internas que não existem neles funçôes regionais ou globais a serem encontradas. Como resultado, a necessidade de enfoque multinível e de coerência de níveis mais altos é descartada com 
desdém. A cantilena de razões para colapsos estruturais é longa.

O sucesso de um trabalho musical repousa sobre uma interpretação instintiva do equilíbrio de funçôes por parte do ouvinte. Além disso, tem-se argumentado nessas discussões que qualquer insatisfação com o funcionamento estrutural pode ser rastreada pelas noções formativas de gesto e textura até as causas espectromorfológicas a partir das quais as funções estruturais são projetadas. $\mathrm{O}$ conceito de grupo-triplo de funções estruturais não é invenção da música eletroacústica. É inerente à nossa experiência do passar do tempo. Mesmo que, na extrema bifurcação da linguagem musical moderna, a espectromorfologia pareça se afastar das noçóes musicais tradicionais, os fundamentos do funcionamento estrutural permanecem.

\section{Relaçôes estruturais}

A Figura 10 mostra a relação de componentes estruturais simultâneos e sucessivos, indicando como agem juntos eventos que são perceptivamente diferenciados em vários níveis estruturais. Todos os termos podem ser usados como suplementos úteis para descrever o funcionamento interno do movimento, do gesto e da textura, do enquadramento de gestos e da configuração de texturas. Eles fazem referência, primordialmente, a ambientes locais e regionais.

A verdadeira independência não é uma realidade musical. É raro, se não impossível, que eventos existentes em simultaneidade deixem de estar relacionados entre si, simplesmente porque colocá-los juntos em um contexto musical lhes confere conexão. Essa conexão é forjada a partir de uma dentre três direçôes. A primeira diz respeito à interação ou equidade relativa, a segunda à reação ou desigualdade relativa, e a terceira - interpolação - aproxima-se mais da independência.

Interação significa cooperação e é representada pela confluência e pela reciprocidade. A reação implica um relacionamento causal ou de concorrência, podendo qualquer um deles envolver graus de representação ativo-passiva. Vicissitude e deslocamento representam métodos de progressão relacionados. Numa progressão vicissitudinosa, um evento cederá voluntariamente ao próximo. Tal seria a relação em uma textura sujeita a transformação morfológica gradual e contínua. A progressão por deslocamento, por outro lado, expressa a resistência de um evento em ser substituído. Interpolação é ou interrupção ou alteração de um só golpe. 


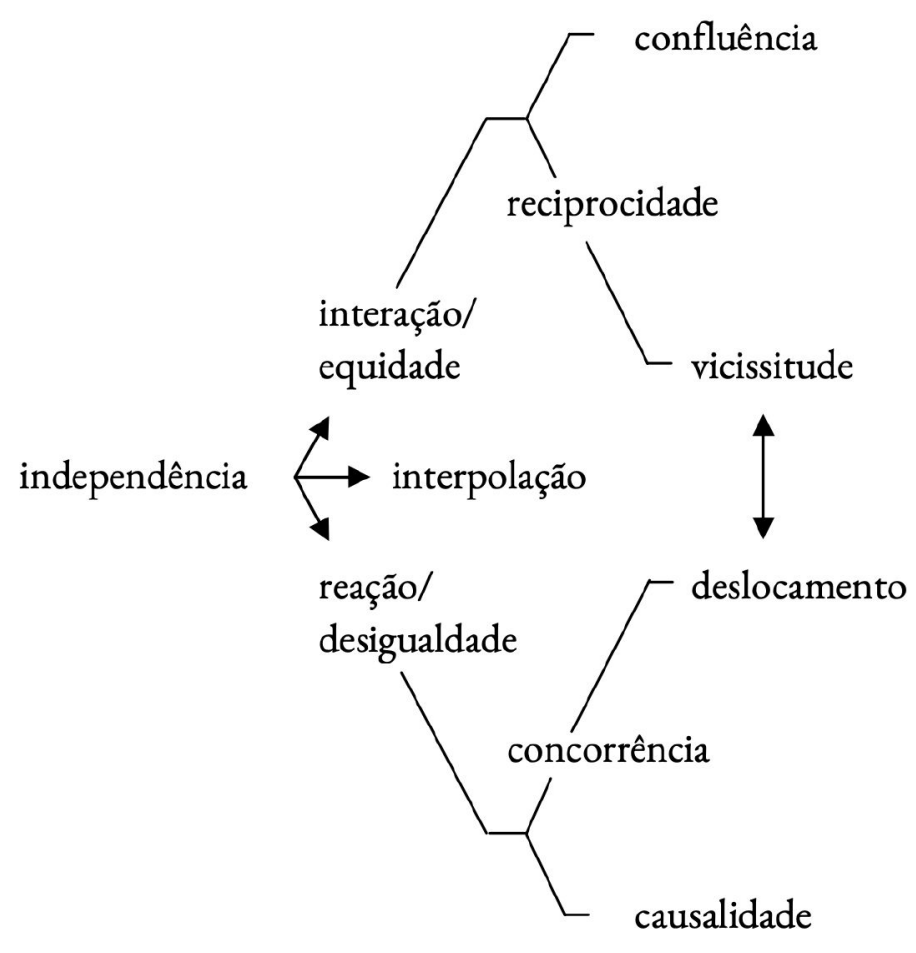

Forma

A música eletroacústica descobriu novas formas? Evitamos, com cuidado, a palavra 'forma', pois ela historicamente passou a indicar uma relativa consistência de projeto estrutural externo comum a vários ou muitos compositores. Ao invés disso, adotamos os termos 'estrutura' e 'processo de estruturação', aplicando-os às unidades e dimensões da obra musical, tanto de níveis de base quanto de níveis mais altos. A ideia de qualquer consenso formal fixo é inimiga da diversidade sem precedentes dos materiais espectromorfológicos. Além disso, a antiga ideia de "forma musical” é baseada nas virtudes cardinais fixas e mensuráveis da altura e do tempo métrico. A espectromorfologia não se baseia em quantidades, mas na percepção de qualidades cuja natureza complexa resiste à sistematização permanente ou semipermanente que é necessária como fundamento do consenso formal. Portanto, é melhor não utilizar o termo para evitar a confusão com as noçôes tradicionais do que é forma. Entretanto, percebemos que deve haver um consenso sobre os processos de estruturação para que a música espectromorfológica seja compreendida entre seus ouvintes. A partir desses fundamentos naturais, uma proliferação de configurações estruturais novas e únicas tem sido composta. 
Espaço

O espaço foi deixado para o final, em primeiro lugar porque é necessário um conhecimento prévio do todo o grande conjunto de nossas discussóes e, em segundo lugar, porque leva às circunstâncias nas quais a música eletroacústica é ouvida e interpretada pelo ouvinte. O espaço é um tópico cuja volumosa capacidade só pode ser rapidamente tocada neste ensaio. Há cinco dimensóes a partir das quais consideramos o espaço: espaço espectral, tempo como espaço, ressonância, articulação espacial na composição e transferência da articulação espacial composta para o ambiente de escuta.

Já observamos a propensão da textura espectral para sugerir analogias espaciais. Parece que reagimos negativamente a qualquer restrição contínua da tessitura do espaço espectral. Um certo equilibrio da propagação espectral é esperado no decorrer de um trabalho. Câimbras espectrais são uma deficiência comum na música eletroacústica e, em geral, podem ser diretamente atribuídas à inadequada qualidade do som.

O movimento espectral é percebido no tempo, e foi apontada a capacidade do projeto espectromorfológico de criar movimentos espaciais reais e imaginados sem a necessidade de se recorrer ao movimento espacial real. O espaço espectral e o tempo como espaço são os dois primeiros aspectos do espaço comuns a todas as músicas.

O terceiro aspecto, ressonância, é também universal. Os ressonadores sempre foram integrados às morfologias instrumentais e vocais. Eles são responsáveis por garantir a continuação do som além da fase de início e possibilitam a projeção acústica das qualidades espectrais. A ressonância, assim, é uma propriedade morfológica onipresente. É um espaço interior, fechado, um determinante causal do comportamento espectral. Na composição eletroacústica, podemos aproveitar esses espaços internos para desenvolver novas morfologias. Podemos estender novas ressonâncias imaginadas, criando estruturas cuja coerência textural retém a lógica interna da instigação de ressonância, mas pode-se expandi-la para a fantasia. Estas são as estruturas de ressonância, híbridos de gesto e textura, expandidas a partir do segundo arquétipo morfológico.

A articulação espacial na composição é filha da música eletroacústica. Se considerarmos a ressonância como o espaço interno, a articulação espacial será, então, o espaço externo onde uma 
estrutura sonora interage com as propriedades do ambiente acústico que ele habita. É a ressonância no exterior de uma morfologia, também conhecida como reverberação.

FIGURA 11 - Articulação espacial

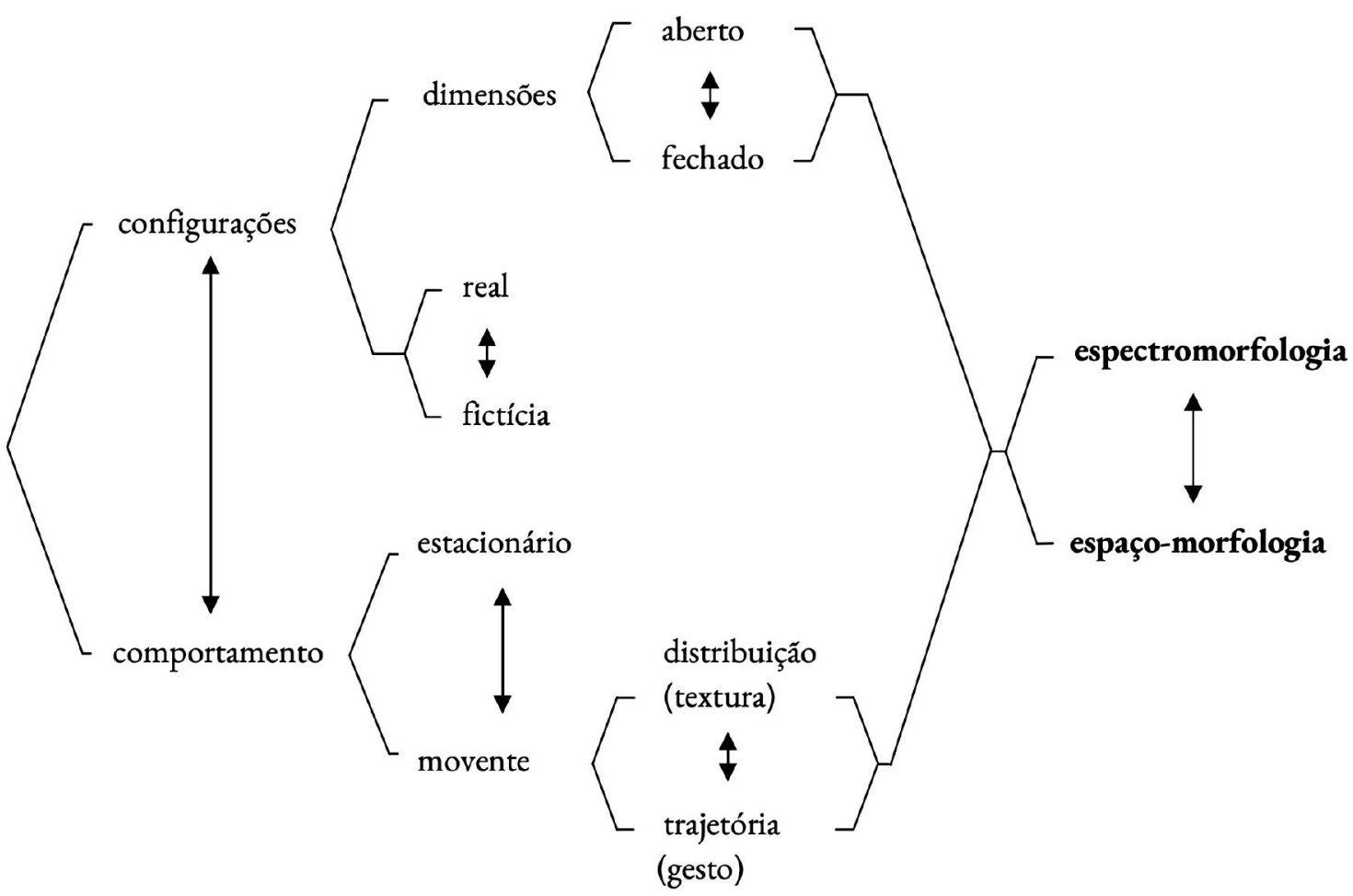

As propriedades relevantes da articulação espacial estão apresentadas na Figura 11. Identificamos uma configuração espacial que possui dimensões ora confinadas por superfícies refletoras, ora deixadas mais abertas, como no ambiente. Um espaço realista é uma configuração plausível, enquanto um espaço fictício ou mudanças de espaços não poderiam existir na realidade. A configuração é deduzida do comportamento espacial, capaz de abranger um imenso repertório de movimentos, mas não independentemente do projeto espectromorfológico e do seu movimento.

Existem duas estratégias comuns, ambas diretamente relacionadas aos conceitos colaborativos de gesto e textura. O gesto se reflete em trajetórias espaciais e a textura, na distribuição espacial dos componentes. A percepção das funçôes estruturais pode ser esclarecida, delineada, aprimorada ou obscurecida através das funções combinadas de trajetória e textura espacial. Assim, a articulação espacial atua como um árbitro da articulação espectromorfológica e estrutural. Um espaço adequado é criado para articular a estrutura musical. 
Mas a interação entre estrutura sonora e espaço pode resultar em transformação morfológica. As consequências serão percebidas através de alterações na riqueza e clareza espectral devido ao distanciamento e à velocidade, e talvez também a alteraçôes no contorno espectral caso a velocidade seja rápida o suficiente para causar efeitos Doppler. Assim, a articulação espacial pode se tornar um determinante morfológico.

Uma terceira situação é possível. Pode ser que uma morfologia seja definida em uma sequência de espaços, de tal forma que nenhuma mudança morfológica significativa ocorra. Diagnosticamos uma mudança de perspectiva espacial por meio de alterações nas propriedades reflexivas, e percebemos uma transformação do espaço, ao invés da morfologia. Desta maneira, a interpretação aural do espaço atinge um novo status estrutural. Este novo elemento musical será denominado espaço-morfologia e, na Figura 11, observe sua interação musical com a espectromorfologia em um continuum que, em um extremo, enfoca a informação espacial obtida por meio da espectromorfologia e, no outro, exibe uma tendência mais frequente de se concentrar na informação espectromorfológica.

O quinto aspecto espacial está envolvido no processo de escuta, em que a música é transferida via alto-falantes para um novo espaço acústico - o ambiente de escuta. Nem os meios de transferência eletroacústica nem o espaço final são neutros: ambos afetam a substância e a estrutura musicais. Na performance, é o quinto aspecto que pode fazer ou desfazer uma estrutura musical. Este último ato de adaptação e de interação espacial envolve uma reinterpretação da estrutura musical para o ouvinte, de forma que se comporte de maneira apropriada às dimensóes e propriedades acústicas do espaço final. É uma questão de adaptar o gesto e a textura para que o foco multinível seja possível para o maior número possível de ouvintes, e, se o espaço corroer os detalhes de baixo nível, medidas preventivas devem então ser tomadas. Esta é a frágil arte da difusão sonora. Em um medium que se baseia na observação e discriminação de diferenças qualitativas, em que critérios espectrais são em grande parte o produto da qualidade do som, este ato final torna-se o mais crucial de todos. 


\section{Conclusão}

Há duas facetas da música eletroacústica que precisariam ser examinadas para uma perspectiva mais completa do medium. Estes são a linguagem e a mimese. $\mathrm{O}$ uso de palavras na música eletroacústica foi ignorado neste capítulo porque envolve uma investigação separada, antes de considerar sua incorporação na música; e, além de observar como a música está indissociavelmente ligada à mimese, deixamos a discussão desse tópico para outros, comentando apenas que qualquer mensagem extramusical transmitida em um trabalho fortemente mimético é veiculada e articulada pela espectromorfologia.

A variedade de fontes sonoras disponíveis como material para a música eletroacústica e o alcance da influência da espectromorfologia demonstram uma ampliação sem precedentes de nossa concepção sobre a natureza da música, exigindo do compositor uma compreensão muito mais profunda e ampla do papel do som na vida do ser humano, assinalando para aquelas pessoas em muitas outras disciplinas que as preocupações musicais invadem sua área de influência, mostrando ao musicólogo a necessidade de conhecimento e pesquisa interdisciplinar, e convidando o ouvinte a participar de maneira mais completa e pensativa do mundo dos sons: a música permeia a vida como nenhuma outra arte. Talvez, como resultado das preocupaçôes da música eletroacústica, possamos imaginar uma nova e mais universal estirpe de músicos, cujas habilidades e iluminações possam recriar, para a música, a posição central que ela outrora manteve na cultura.

Concluindo, afirmamos que o rápido desenvolvimento da espectromorfologia é a mudança mais radical da história musical ocidental. Em menos de cinquenta anos, os materiais da música mudaram completamente, e agora devemos entender que o pensamento espectromorfológico é o legítimo herdeiro da tradição musical ocidental. ${ }^{12}$ A espectromorfologia reafirma a primazia da percepção auditiva, que tem sido tão terrivelmente ignorada no passado recente, e adverte compositores, pesquisadores e tecnólogos que, a menos que seja permitido que o julgamento aural triunfe sobre a tecnologia, a música eletroacústica atrairá merecida condenação.

\footnotetext{
${ }^{12}$ Nenhuma obra foi mencionada neste capítulo. O que sugerimos é que nenhuma obra eletroacústica está imune às questôes consideradas. Duas obras podem ser particularmente recomendadas para o estudo, devido a sua incorporação compreensiva da maioria das questôes espectromorfológicas: Kontakte, de Karlheinz Stockhausen, e De Natura Sonorum, de Bernard Parmegiani.
} 


\section{REFERÊNCIAS}

BOULEZ, Pierre. [Texto de encarte]. In: Le temps musical 1. Paris: Radio France/IRCAM, 1978. Fita cassete.

CHION, Michel. Guide des objets sonores. Paris: Buchet Chastel/INA GRM, 1983.

GEORGIADES, Thrysabulos. Music and Language: The Rise of Western Music as Exemplified in Settings of the Mass. GÖLLNER, Marie Louise (trad). Cambridge: University Press, 1982.

HARVEY, Jonathan. Reflection after Composition. Contemporary Music Review, United Kingdom, Vol. I, Nº1, p. 83-86, 1984.

HEIKINHEIMO, Seppo. The Electronic Music of Karlheinz Stockhausen. Helsinki: Suomen Musiikkitieteelinen Seura, 1972

SCHAEFFER, Pierre. Traité des objets musicaux. Paris: Éditions du Seiul, 1966.

\section{SOBRE O AUTOR}

Denis Smalley, nascido na Nova Zelândia em 1946, estudou música na Universidade de Canterbury e na Universidade Victoria de Wellington, antes de estudar com Olivier Messiaen no Conservatório de Paris, e no Groupe de Recherches Musicales (GRM). Em 1972, mudou-se para a Inglaterra, concluindo o doutorado em composição na Universidade de York. Até 1994, foi professor titular e diretor do estúdio de música eletroacústica da Universidade de Ânglia Oriental. Mudou-se, então, para a City University, Londres, como Professor de Música e Chefe do Departamento de Música. Aposentou-se da instituição em 2009 e agora é Professor Emérito.

\section{SOBRE OS TRADUTORES}

Germán Gras nasceu na Argentina, onde formou-se em composição pela Universidade Nacional do Litoral (UNL). Tem mestrado e doutorado em Composição pela Universidade Federal de Rio Grande do Sul (UFRGS), sob orientação de Celso Loureiro Chaves. Atua como professor substituto no curso de música da Universidade Estadual do Ceará (UECE), desde 2014. ORCID: https://orcid.org/0000-0003-1635-1262. E-mail: pajaro_gras@yahoo.com.ar

Thaís Amorim Aragão é doutora em Comunicação pela Universidade do Vale do Rio dos Sinos (UNISINOS), com estágio doutoral na Escola de Mídias, Artes e Design da Universidade de Westminster, em Londres, e mestra em Planejamento Urbano e Regional pela Universidade Federal do Rio Grande do Sul (UFRGS). Atua como produtora cultural na Rádio Universitária FM, emissora da Fundação Cearense de Pesquisa e Cultura ligada à Universidade Federal do Ceará (UFC). ORCID: https://orcid.org/0000-0003-3549-5261. E-mail: thais.aragao@ufc.br 